\title{
O Que Faz o Gelo Derreter Mais Rápido?
}

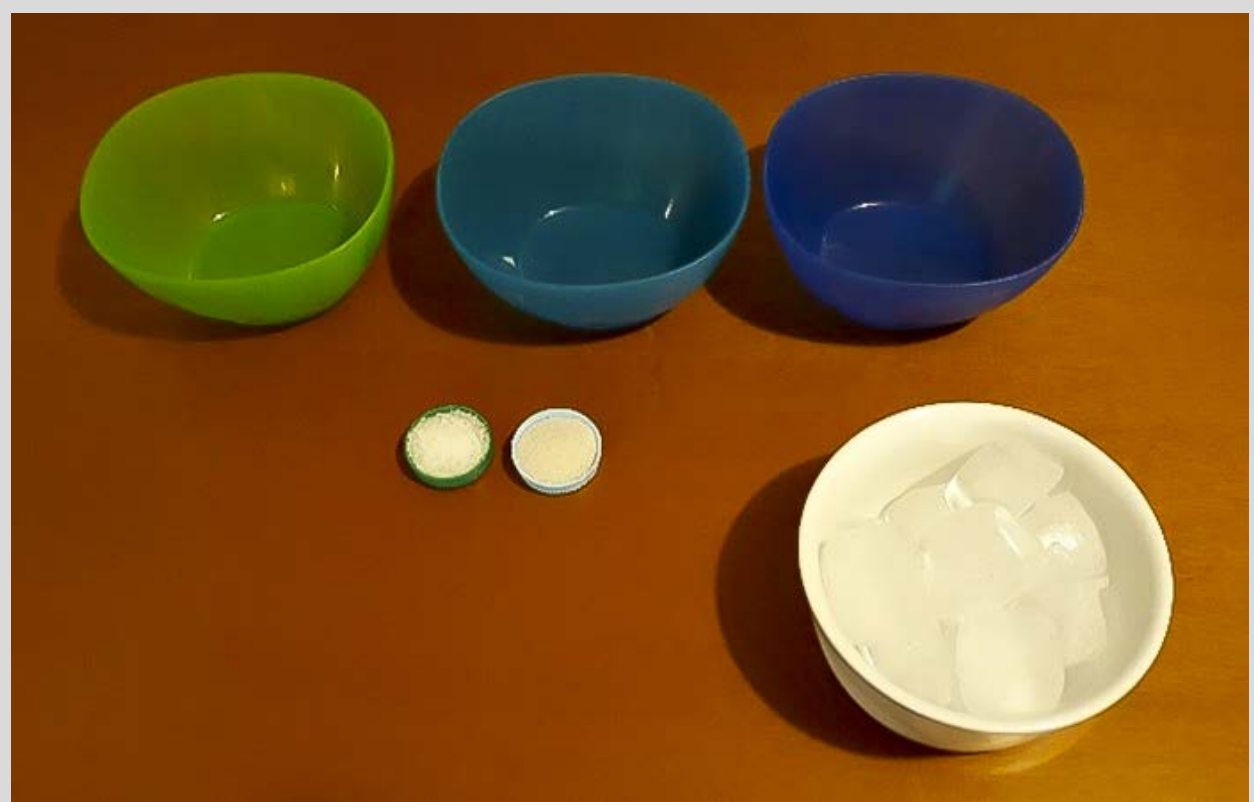

\section{Introdução}

Em atividades passadas recorremos a um banho de gelo e sal para fazer gelados. Nessa ocasião utilizámos o mesmo princípio com que se costuma evitar que as estradas nas regiões mais frias congelem no inverno. Nesta edição iremos investigar o que acontece ao estado físico da água, na presença de outras substâncias.

\section{Material}

- 9 cubos de gelo

- 3 recipientes

- Tampa de garrafa de plástico com sal de cozinha

- Tampa de garrafa de plástico com areia

\section{Procedimento}

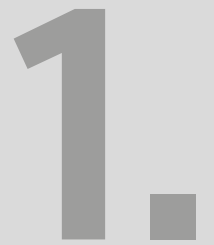

Colocar três cubos de gelo em cada recipiente de modo a que se toquem somente nos cantos.

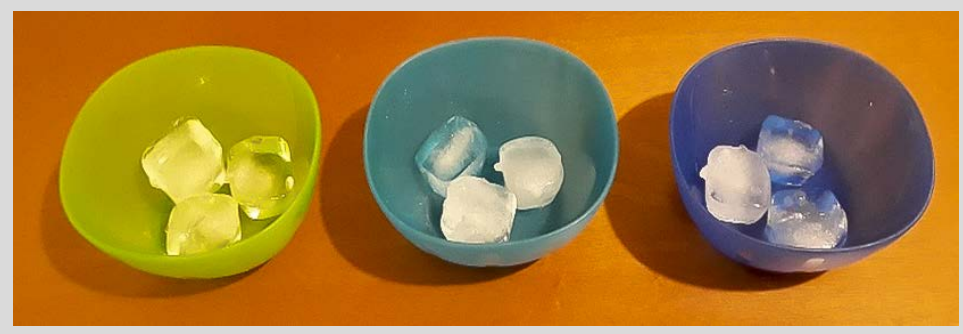




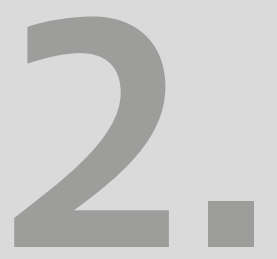

Adicionar rapidamente $1 / 2$ colher de chá de sal ao primeiro recipiente, espalhando por cima dos cubos de gelo e, no segundo recipiente, adicionar $1 / 2$ colher de chá de areia. 0 terceiro recipiente será o controlo.

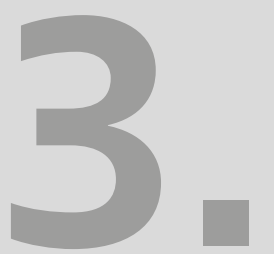

Verificar a quantidade de água no estado líquido após 30 minutos. Alternativa: colocar todos os recipientes no frigorífico e verificar a evolução de hora a hora.
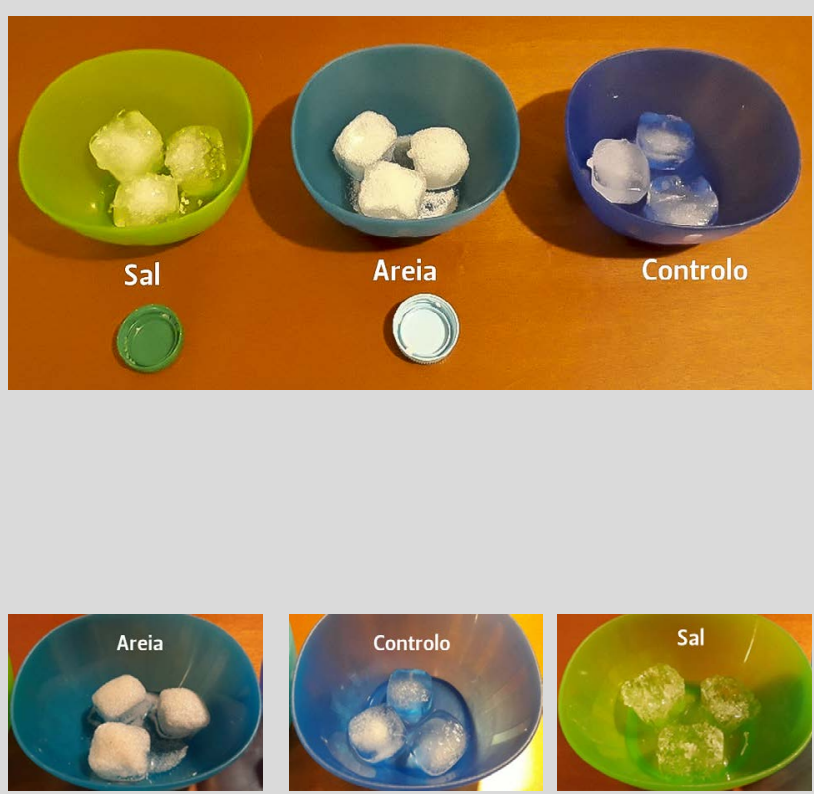

\section{Referências}

[1] Adaptado de Science Buddies Staff. (2017, July 28). What Makes Ice Melt Fastest?, sciencebuddies.org/science-fair-projects/project-ideas/Chem_ p049/chemistry/what-makes-ice-melt-fastest (consultado em 15/10/2019).

\section{Marta C. Corvo}

É investigadora no i3N|CENIMAT, Dep. Ciência dos Materiais da Faculdade de Ciências e Tecnologia da Universidade NOVA de Lisboa, dedicada à ressonância magnética nuclear. Além da divulgação de ciência, interessa-se pelo desenvolvi-

mento de novos materiais para captura de $\mathrm{CO}_{2}$, armazenamento de energia e preservação de obras de arte.

marta.corvo@fct.unl.pt ORCID.org/0000-0003-0890-6133 